\section{Birlesik Dunya Arastrrma Cypriot Journal of Educational BD-CENTER \\ Sciences}

Innovasyon ve Yayıneılık Merkezi
Volume 16, Issue 3, (2021) 1244-1254

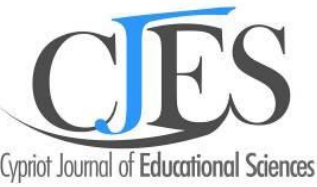

www.cjes.eu

\title{
Professionally oriented training of specialists to work in the conditions of the inclusive educational environment
}

Olekcii Tohochynskyi a *, President Academy of the State Penitentiary Service, Honcha str. 34, Chernihiv, 14000, Ukraine https://orcid.org/0000-0002-8170-6237

Serhii Yermak ${ }^{\text {b }}$, Faculty of Advanced Training of the Staff of the Penitentiary Service of Ukraine, Academy of the State Penitentiary Service, Honcha str. 34, Chernihiv, 14000, Ukraine https://orcid.org/0000-0002-5069-1001

Alla Popryzhna c, Department of Economics and Social Sciences, Academy of the State Penitentiary Service, Honcha str. 34 , Chernihiv, 14000, Ukraine https://orcid.org/0000-0002-5079-2865

Miroslav Turdon d, Department of Social Work and Social Sciences, Constantine the Philosopher University in Nitra, Tr. A. Hlinku 1, 94901, Nitra-Chrenova, Slovakia https://orcid.org/0000-0002-0020-4201

Nataliya Oleksiuk e, Department of Social Pedagogy and Social Work, Ternopil National Volodymyr Hnatyuk Pedagogical University, 2 Maxyma Kryvonosa str., 46027, Ternopil, Ukraine https://orcid.org/0000-0002-1538-1470

\section{Suggested Citation:}

Tohochynskyi, O.; Yermak, S.; Popryzhna, A.; Tvrdon, M. \& Oleksiuk, N. (2021). Professionally oriented training of specialists to work in the conditions of the inclusive educational environment. Cypriot Journal of Educational Science. 16(3), 1244-1254. https://doi.org/10.18844/cjes.v16i3.5844

Received from January 11, 2020; revised from April 23, 2021; accepted from June 16, 2021. (C)2021 Birlesik Dunya Yenilik Arastirma ve Yayincilik Merkezi. All rights reserved

\begin{abstract}
It is confirmed that the efficiency of an inclusive educational environment functioning is ensured by the presence of diversified psychological and pedagogical professionals and their proficient cooperation. The training of these professionals is of top priority while developing inclusive education in Ukraine. The results obtained during the pedagogical experiment convincingly prove that the author's developed and tested methods and teaching and methodological materials allow directing the educational process to the training of future diversified psycho-pedagogical professionals to work in the conditions of the inclusive educational environment. During the formative stage of the pedagogical experiment, research and experimental work were carried out to check the effectiveness of the specialist training system of the psycho-pedagogical field to work in the conditions of a functioning of the inclusive educational environment. In order to obtain empirical data and to ensure their validity, a questionnaire and methodology to diagnose the levels of formation of bachelors' professional competence were developed, in the context of which the criteria and levels of formation of the investigated quality were defined, as well as the tools for its implementation were created.
\end{abstract}

Keywords: Inclusive educational environment, a child with special educational needs, control and experimental groups, psychopedagogical specialist, educational trajectory.

* ADDRESS FOR CORRESPONDENCE: Olekcii Tohochynskyi, Academy of the State Penitentiary Service, Honcha str. 34, Chernihiv, 14000, Ukraine

E-mail address: oxiko00@mail.ru / Tel.: +380675812948 


\section{Introduction}

The national educational system reform, which is currently taking place in Ukraine, actualises the training problems of the staff who are able to work in accordance with the new methodological guidelines, which are outlined by the New Ukrainian School concept. Among them, the prominent position is taken by inclusive education (IE) which serves as an educational paradigm that is based on the worldview of social inclusion, because the equality, accessibility and quality assurance are the fundamentals imperative of its functioning.

The development of an inclusive educational system requires the determination of the methodological bases for specialists training in the psycho-pedagogical field who are directly involved in the organisation and ensuring of an effective functioning of the inclusive educational environment (IEE), which is based on the professional's ability to perform the role of a mentor, tutor and moderator and to determine the individual educational trajectory of a child with special educational needs (SEN).

At the same time, as the practice shows, the willingness of the psycho-pedagogical staff to work in inclusive educational environment is extremely poor. One of the obvious reasons is the lack of systematic training of the psycho-pedagogical specialists in the institutions of higher education.

The research concept is determined by the process of inclusive education development in Ukraine and the peculiarities of its introduction. The main idea of the concept is to lay out the formation of the professional competence of future psycho-pedagogical specialists for IE in the teacher training institutions of higher education. The research is a scientific basis for solving the problem of a competent specialist's formation, who is able to effectively realise his/her professional potential in a team cooperation in conditions of IEE. The solution of the outlined problem is possible on condition that there is an introduction of the curriculum for training of diversified psycho-pedagogical staff for the needs of inclusive education in the educational process. The curriculum should provide an integration of inclusively oriented educational content, aimed at the creation of a higher level of professional competence formation through methodological coordination of the pedagogical conditions of theoretical and practical training. The unity and integrity of all the system components of the staff training in the psycho-pedagogical field to work in the conditions of IEE (conceptual, target, substantial and procedural) allow to predict, define and adjust personal professionally oriented trajectory of the vocational training of every graduate during the whole period of studies.

\section{Materials and methods}

The relevance of the training and re-skilling of the psycho-pedagogical staff to work in the conditions of IEE is determined, in particular, by the following factors:

- $\quad$ Rapid implementation of inclusive education during the last years;

- Insufficient awareness of specialists in the methodological principles of IE, in technological and methodological means of inclusive education implementation;

- Increasing of the academic component in the formation of the practical professional competences of students, which are necessary for working with children with SEN in the conditions of IEE;

- Insufficient awareness of higher education teaching personnel on the importance, peculiarities and contents of the psycho-pedagogical staff performance in the conditions of IEE. 
Tohochynskyi, O.; Yermak, S.; Popryzhna, A.; Tvrdon, M. \& Oleksiuk, N. (2021). Professionally oriented training of specialists to work in the conditions of the inclusive educational environment. Cypriot Journal of Educational Science. 16(3), $1244-1254$. https://doi.org/10.18844/cjes.v16i3.5844

\subsection{Problem statement}

The analysis of the scientific sources and generalisation of the domestic experience in the implementation of the inclusive model of education in the pedagogical practice of the pre-school and secondary general educational establishments gave an opportunity to define theoretical problems in staff training for inclusive education in the form of the following contradictions:

- $\quad$ On the socio-pedagogical level: between a social order for the introduction of the inclusive model of education into the modern domestic pedagogical practice and insufficient number of qualified psychopedagogical staff who are able to provide work to children with SEN in the conditions of IEE;

- $\quad$ On the scientific-theoretical level: between a need for psychological and pedagogical staff training to work in the conditions of IEE and the lack of an effective system of such training and theoretical justification of its content;

- $\quad$ On the practical and methodological level: between a need for an inclusive practice implementation and psychological and pedagogical staff training and between the lack of programme teaching materials to provide development of the professional competences of the corresponding specialists.

Therefore, poor elaboration of the psychological and pedagogical staff-training problem to work with children with SEN in the conditions of IEE has determined the choice of the research theme.

\subsection{Literature review}

The experience of social and educational inclusion indicates the search of methodological bases for IE problem investigation. Theoretical foundations of an inclusive education model are based on the integrated systematic researches of scientists.

It becomes obvious that all the modern socio-philosophical concepts influence the formation of a new educational paradigm, which will lead to the synthesis of theories aimed at a search and implementation of optimum inclusive practices (Barton, 2018).

At the methodological level of our research, the leading idea was stated, which, in our opinion, can be put into the bases of the modern concept of inclusive education (Appiah-Kubi \& Annan, 2020; Billingsley, McLeskey \& Crockett, 2019). At this stage of the research, we consider it expedient to analyse philosophical bases of the methodology of the inclusion modelling (Atoum, 2019; Clark, Dyson \& Millward, 2018).

While studying the philosophical problems of the inclusion it is impossible to neglect the issue of pedagogical anthropology. Modern pedagogical anthropology aims to identify practical ways of the holistic study of human qualities. The task of a teacher is to support the development of the inner world of a child, to strengthen this position, not to hurry to raise it to the next one and for it to be a 'more progressive' position. Pedagogical anthropology views a child in a dialogue with 'the others' (other person), such as the role of a teacher, parents or the other pupil (Engelbrecht, Savolainen, Nel, Koskela \& Okkolin, 2017).

The personal-social activity approach (Fabiano, Reddy \& Dudek, 2017; Haug, 2016; McLeskey et al., 2017) is expressed in comprehension of a child's nature, the experience of her/his sensory life through socially determined spatiotemporal speech environment. The suggested integrative social pedagogical paradigm is especially valuable for studying and substantiating the ways and mechanisms of building the social space of relationships as a factor of upbringing and socialisation of children, taking into account their peculiarities and abilities. According to the author's opinion, such an optimal space for a development of a child with SEN is an inclusive educational environment. 
Tohochynskyi, O.; Yermak, S.; Popryzhna, A.; Tvrdon, M. \& Oleksiuk, N. (2021). Professionally oriented training of specialists to work in the conditions of the inclusive educational environment. Cypriot Journal of Educational Science. 16(3), $1244-1254$. https://doi.org/10.18844/cjes.v16i3.5844

The essence of a social theory of autopoiesis lies in the necessity to provide every child with an individual educational route that is focused on an active communicative interaction with social environment, which allows to adequately check the received knowledge and skills. From the standpoint of these concepts, IE is implemented through a socially built individual educational route (Messiou, 2017; Morina, 2017).

The formation of the pedagogical process as a dialogue between the participants of the educational space suggests a high level of professional competence of a teacher; that is why a competency-based approach in inclusive education is of particular value for the investigation and modelling of inclusive processes (Morina, 2017). A competency-based approach is a relatively new perspective in the research of education problems. The studies of professional pedagogical activity from the angle of the competencybased approach assure that it has become an integral part of the general development strategy and comprehension of modern IE problems and allow representing the results of education as systematic integrative qualities which provide successful solutions for important professional tasks (Ware, 2018).

The implementation of inclusive practice is connected with the distinguishing and meaningful description of a teacher's competence as a combination of personal and professional qualities which activate right in the innovative conditions of IEE and give an opportunity to successfully complete the tasks connected with the organisation of education and upbringing of all children, regardless of their specific educational problems (Yada \& Savolainen, 2017).

The polyfundamental approach (O'Hanlon, 2017) allows to systematically, from different methodological positions, comprehend the inclusion specification and to find a way to solve the problems, which slow down and misrepresent the process of inclusive education implementation.

A humanistic paradigm of the public consciousness is built on the idea that the modern world is based on the integrated humanistic system of values where traditions are respected and innovations are accepted, and where dialogic and equitable relationships between people are established no matter what capabilities (intellectual, physical and others) a person possesses (Qvortrup \& Qvortrup, 2018).

Thus, modern IE is a structurally innovative educational system, which determines the change of a social system of a state. At the same time, psychological and pedagogical support of children with SEN in the conditions of a mass educational institution should become closer to the tasks of the society change on the basis of tolerance, humanism and professional competence according to a new educational paradigm (Udvari-Solner \& Thousand, 2018).

Within the framework of formation of pan-European educational space, the problem of improving the training and retraining of psycho-pedagogical staff for inclusive education in Ukraine has become particularly relevant.

The problems of professionalism formation of psychological and pedagogical specialists are connected with high-level requirements, which are dictated by the modern society and professional community regarding the organisation of the pedagogical activity. It demands constant improvement of personal features, increase in existing and acquiring new knowledge and orienting each specialist to personal growth and professional excellence. A way to solve this task is through a concept of continuing education, which determines new approaches to educational system design, to the contents of pedagogical process and the sequence of its levels (Tomlinson, 2018).

Human resource policies in the field of inclusive education may be successfully implemented if the developed strategies are grounded on the scientific concept of reformation and its implementation mechanisms. Scientific explorations of Saloviita (2018) foresee several options in the training of psychopedagogical staff for inclusive education - from retraining of specialists of mass educational institutions in 
Tohochynskyi, O.; Yermak, S.; Popryzhna, A.; Tvrdon, M. \& Oleksiuk, N. (2021). Professionally oriented training of specialists to work in the conditions of the inclusive educational environment. Cypriot Journal of Educational Science. 16(3), $1244-1254$. https://doi.org/10.18844/cjes.v16i3.5844

the system of postgraduate education to the introduction of new combined specialties which will provide graduates with universal knowledge.

According to Slee (2018), an insufficient level of professional competence of specialists in the mass educational institutions in the field of inclusive education reveals an existence of a serious problem in modern higher education which cannot be solved by special education staff and using existing traditional technologies.

In the context of our investigation, it is important to study theoretic and methodological provisions of training of psycho-pedagogical staff in the higher educational institutions of Ukraine for the introduction of inclusive education. Today, there is a sharpened contradiction between the traditional system of special pedagogical staff training and needs of practice, in which psycho-pedagogical specialists of mass educational institutions become necessary, who are able to provide a child with SEN with qualitative educational services in the conditions of IEE.

To solve the outlined tasks and to ensure the veracity of the theses and conclusions of the study, a complex of mutually complementary methods was used, as follows:

- Theoretical: retrospective comparative logical analysis of philosophical, psycho-pedagogical and methodological literature for the development of theoretical foundations of the psycho-pedagogical staff training system to work in the conditions of IEE; systematisation, synthesis, generalisation for comparing and matching of philosophical and pedagogical views on different aspects of the studied problem, definition of the conceptual and categorical apparatus.

- Empirical: diagnostic (conversations, tests, questionnaires, surveys and interviews) and observational (psycho-pedagogical monitoring and self-evaluation) in order to find out the formation level of the professional competence; pedagogical experiment to prove the effectiveness of the training system of specialists in the psychological pedagogical field to work in the conditions of IE;

- $\quad$ Of mathematical statistics (statistical processing of empirical data, graphic display of results and Pearson's criterion) for quantitative and qualitative analysis of the results received during the pedagogical experiment.

The reliability of the received results is provided by methodological and theoretical substantiation of the starting points of the investigation; by using the system of methods which are adequate to the purpose, subject and tasks of the research, by the representativeness of the sample; by combination of quantitative and qualitative analysis of the empirical data; and by effectiveness of experimental work which is conducted in the conditions of a real educational process of the teacher training institutions of higher education.

The investigation platform covered the teacher training institutions of higher education which implement bachelors' training in specialties like 'Preschool education', 'Primary education', 'Social pedagogy' and 'Practical psychology', including Poltava State Pedagogical University named after V.G. Korolenko, Sumy State Pedagogical University named after A.S. Makarenko and Pavlo Tychyna Uman State Pedagogical University. A total of 176 psycho-pedagogical workers (educators, primary school teachers, social care teachers and psychologists), more than 40 lecturers of the teacher training institutions of higher education and 673 students participated in the experimental research work

\subsection{Results}

Under the influence of world humanistic requirements, the modern system of education has been in the state of reformation due to socio-economical, political and spiritual-cultural transformation. In modern 
Tohochynskyi, O.; Yermak, S.; Popryzhna, A.; Tvrdon, M. \& Oleksiuk, N. (2021). Professionally oriented training of specialists to work in the conditions of the inclusive educational environment. Cypriot Journal of Educational Science. 16(3), $1244-1254$. https://doi.org/10.18844/cjes.v16i3.5844

education, they implement an idea connected with the change of the target guidance in the education field - from knowledge formation to the formation of competences and from 'a personality for society "to" a personality in the society'. The necessity to update education technology for the purpose of raising the quality of the educational process has become relevant, as well as educational services are capable of ensuring the development of children, regardless of their health condition and social origin.

A characteristic feature nowadays is the improvement of the special education system on the democratic and humanistic principles, the creation of alternative models of psycho-pedagogical support, the free choice mechanisms for the forms of education of children and the level and range of educational needs. The state of modern education indicates partial introduction of humanistic, democratic and axiological bases into the educational process; that is why every form of atypicality (belonging to ethnical, language, cultural, religious minority, giftedness, psychophysical peculiarities, disability etc.) is not considered in the education as a natural condition of coexistence of different people, and this frequently leads to social deprivation and isolation of children who according to certain criteria are different from the majority of their coevals. This humanistic paradigm is embodied by inclusive education, which according to the world pedagogical community is the most powerful innovative movement in the education of the 20th century.

Civil society development contributes to the promotion of democratic values, which are laid out in the basis of inclusive education, since just inclusive education as a fundamental pedagogical condition for success of every child in the adulthood has its clearly outlined value.

In order to study the problems of IE in the context of modern democratic transformations, it is necessary to analyse its philosophy and epistemology, empirical experience of its development and implementation and to realise its relevance and social phenomenon.

During the undergraduation pedagogical practice, using our developed methodology of team professional activity of diversified psycho-pedagogical specialists in the conditions of IEE and teaching and methodological materials for inclusive groups / classes, the students proved that they can not only organise the IEE but also successfully cooperate in its conditions. Future psycho-pedagogical specialists have learnt to plan the educational process: to study the actual level of mental development, cognitive sphere, communication capabilities, peculiarities of emotionally volitional sphere, individual capabilities, mental performance and a pace of mental activity of children with SEN; to define the purpose, to coordinate the time, space, materials and different kinds of activities of the correctional and developmental work with children with SEN; to watch and analyse the progress in the comprehensive development of children with SEN; and to increase the level of educational achievements of children using the technology of differential teaching. As a result of the team work of the future psycho-pedagogical specialists, children with SEN began to freely communicate with their coevals with the typical development and trainees and began to share their problems and achievements. During the experimentally practical activity, children with SEN were partners in classes/lessons conducted, they felt responsible, received better skills to understand their needs and chose methods which would facilitate their learning. During the schooling, according to our methodology, all the children were constantly at the centre of attention. The success of the inclusive class/lesson was increasing as the children became more skilful and helped each other to achieve group and individual goals.

Analysing their own team work, the students stated that the organisation of the team professional activity of the diversified specialists in the conditions of IEE makes the educational process of all the pupils effective and accessible. 
In order to define during the experimental activity a formed level of professional competence of bachelors and to analyse the results of the forming experiment, one more diagnosis was made at the end of the 2016-2017 school year. To diagnose the levels of formation of the studied quality, respondents of the control and experimental groups were offered the same questionnaire, which was used at the initial stage of the forming experiment.

To check the presence or absence of the statistical discrepancy between the parametric values of the studied quality of the respondents of the control and experimental groups, we formulated the two hypotheses:

HO: The difference in the levels of formation of professional competence of the future psychopedagogical staff of inclusive education is insignificant.

H1: The difference in the levels of formation of professional competence of the future psychopedagogical staff of inclusive education is quite significant.

To check the above-mentioned hypotheses we used the nonparametric criterion of Pearson (Pearson's chi-squared test). The selection of the indicated statistical method was conditioned by the execution of the main conditions of its implementation: our sample significantly exceeds the boundary volume of 30 people; determined levels cover all the range of variability of features; and ranges of the respondents' accumulated points are clearly fixed to the levels and do not intersect. Other requirements to the theoretical frequency and quantity of digits were also observed.

Generalised and adapted data, received from the students' personal cards, are presented in Table 1.

Table 1. Quantitative indexes of the distribution of the levels of professional competence formation of students at the final stage of the forming experiment of the control group (CG) and experimental group (EG)

\begin{tabular}{|c|c|c|c|c|c|}
\hline $\begin{array}{l}\text { Institution of higher education of } \\
\text { Ukraine }\end{array}$ & Groups & $\begin{array}{c}\text { Total } \\
\text { number } \\
\text { of people }\end{array}$ & elementary & $\begin{array}{l}\text { Levels, \% } \\
\text { average }\end{array}$ & sufficient \\
\hline \multirow{2}{*}{$\begin{array}{l}\text { Poltava State Pedagogical Univ. } \\
\text { named after V.G. Korolenko }\end{array}$} & CG & 69 & 33.3 & 58.0 & 8.7 \\
\hline & EG & 53 & 34.0 & 49.1 & 17.0 \\
\hline \multirow{2}{*}{$\begin{array}{l}\text { Sumy State Pedagogical Univ. named } \\
\text { after A.S. Makarenko }\end{array}$} & CG & 68 & 35.3 & 58.8 & 5.9 \\
\hline & EG & 70 & 34.3 & 50.0 & 15.7 \\
\hline Pavlo Tychyna Uman State & CG & 115 & 33.0 & 58.3 & 8.7 \\
\hline Pedagogical University & EG & 103 & 33.0 & 49.5 & 17.5 \\
\hline \multirow{2}{*}{ Total } & CG & 252 & 33.8 & 58.3 & 7.9 \\
\hline & EG & 226 & 33.6 & 49.6 & 16.8 \\
\hline
\end{tabular}

The data in Table 2 allow to make a conclusion that qualitative positive changes have happened in the experimental group, in particular the number of students has increased, which demonstrates a sufficient level of professional competence of future specialists in the field of IE (16.8\%). (At the beginning of the experiment this index was 8.4\%.) At the same time, the number of students who achieved an average and low levels reduced by $3.9 \%$ and $4.5 \%$, respectively. 

of the inclusive educational environment. Cypriot Journal of Educational Science. 16(3), $1244-1254$. $\underline{\text { https://doi.org/10.18844/cjes.v16i3.5844 }}$

Table 2. Generalised results of diagnostics of the levels of formation of professional competence of students at different stages of the forming experiment

\begin{tabular}{ccccc}
\hline Groups & $\begin{array}{c}\text { Stages of } \\
\text { experiment }\end{array}$ & Elementary & average & Sufficient \\
\hline \multirow{2}{*}{ CG } & Initial & 36.1 & 56.0 & 7.9 \\
& Final & 33.7 & 58.3 & 7.9 \\
& Initial & 38.1 & 53.5 & 8.4 \\
& Final & 33.6 & 49.6 & 16.8
\end{tabular}

Among the students of the control group, a positive trend in quantitative index was also seen. Thus, according to the results of the analysis, there was an insignificant increase in the number of students who received an average level (56\%) at the beginning of the experiment and at its final stage (58.3\%), and the number of students with an elementary level decreased by $2.3 \%$.

Therefore, without introducing into the educational process of institutions of higher education the system of specialists training in the psycho-pedagogical field developed by us, it is impossible to create such a level of professional competence, which would allow to effectively realise their own potential for bachelors' graduates in the conditions of IEE.

However, the results of the analysis still need to be confirmed by the methods of mathematical statistics. Summarised data are presented in Table 3.

Table 3. Summarised results of diagnostics of the levels of formation of professional competence of students (at the final stage of the forming experiment)

\begin{tabular}{|c|c|c|c|c|c|c|c|c|}
\hline \multirow{3}{*}{ Groups } & \multirow{3}{*}{$\begin{array}{c}\text { Total } \\
\text { number } \\
\text { of } \\
\text { people }\end{array}$} & \multirow{3}{*}{$\begin{array}{l}\text { Rate, } \\
\text { di }\end{array}$} & \multicolumn{6}{|c|}{ Levels } \\
\hline & & & \multicolumn{2}{|c|}{$\begin{array}{c}\text { Elementary } \\
m_{1}^{*}\end{array}$} & \multicolumn{2}{|c|}{$\begin{array}{c}\text { Average } \\
m_{2}^{*}\end{array}$} & \multicolumn{2}{|c|}{$\begin{array}{c}\text { Sufficient } \\
m_{3}^{*}\end{array}$} \\
\hline & & & People & $\%$ & People & $\%$ & People & $\%$ \\
\hline$C G$ & 252 & 0.527 & 85 & 33.8 & 147 & 58.3 & 20 & 7.9 \\
\hline EG & 226 & 0.473 & 76 & 33.6 & 112 & 49.6 & 38 & 16.8 \\
\hline
\end{tabular}

Let us check the empirical data that we received to prove or refute the hypothesis set up by us with regard to the fact that the difference in the levels of formation of professional competence of the future psycho-pedagogical specialists in inclusive education in the experimental and control groups after the introduction of the author's system of training is significant enough.

Generalised results of the final stage of the forming experiment are presented in Table 4. 

of the inclusive educational environment. Cypriot Journal of Educational Science. 16(3), 1244-1254. $\underline{\text { https://doi.org/10.18844/cjes.v16i3.5844 }}$

Table 4. Calculations of Pearson's criterion (at the final stage of the forming experiment)

\begin{tabular}{|c|c|c|c|c|c|}
\hline Levels & $\begin{array}{l}\text { Empirical } \\
\text { frequencies }\end{array}$ & $\begin{array}{l}\text { Theoretical } \\
\text { frequencies }\end{array}$ & $m_{i}^{*}-m_{i}$ & $\left(m_{i}^{*}-m_{i}\right)$ & $\chi_{i m p}^{2}$ \\
\hline CG (elementary) & 85 & 84.9 & 0.12 & 0.01 & 0.000 \\
\hline EG (elementary) & 76 & 76.1 & -0.12 & 0.01 & 0.000 \\
\hline CG (average) & 147 & 136.5 & 10.46 & 109.33 & 0.801 \\
\hline EG (average) & 112 & 122.5 & -10.46 & 109.33 & 0.893 \\
\hline CG (sufficient) & 20 & 30.6 & -10.58 & 111.88 & 3.659 \\
\hline EG (sufficient) & 38 & 27.4 & 10.58 & 111.88 & 4.080 \\
\hline Total & 478 & 478.0 & 0.00 & - & 9.433 \\
\hline
\end{tabular}

The results, received in the control and experimental groups while conducting the final stage of the forming experiment, indicate the tendency to increase differences between them: $=9.433$ (as compared to $9.433>5.991[<0.05])$.

Accordingly, the methods found pairwise comparison of groups (experimental and control groups, before the start and at the end of the forming experiment). The results of calculations are shown in Table 5.

Table 5. Empirical value of the criterion for control and experimental groups at the stage of the forming experiment

\begin{tabular}{lcccc}
\hline & $\begin{array}{c}\text { CG initial } \\
\text { stage }\end{array}$ & $\begin{array}{c}\text { EG Initial } \\
\text { stage }\end{array}$ & CG final stage & EG final stage \\
\hline CG initial stage & - & 0.280 & 0.330 & 8.870 \\
EG initial stage & 0.280 & - & 1.143 & 7.298 \\
CG final stage & 0.330 & 1.143 & - & 9.433 \\
EG final stage & 8.870 & 7.298 & 9.433 & -
\end{tabular}

The cells in Table 5 show empirical values of the criterion for the compared groups, which match the columns and rows. The value of the criterion is highlighted in bold, which was received at the initial stage $(0.280[<0.05])$ and the final stage of the forming experiment $(9.433[<0.05])$.

Characteristics of all the compared samples, except the experimental and control groups at the final stage of the forming experiment, coincide with the level of significance 0.05 (i.e., the criterion value). Since the received value $=9.433>5.991$, then the precision of deviation between the characteristics of the experimental and control groups after the forming experiment is finished is $95 \%$. Therefore, the null hypothesis is refuted and it confirms our hypothesis that the effect of changes is ensured by the training system of specialists in the psychological pedagogical field to work in the conditions of IEE which were offered by us.

\section{Conclusion}

In the course of the experimental work, the methodology of bachelors' training of the psychopedagogical field to work in the conditions of IEE was developed and introduced, which aimed at the creation of professional competence on the basis of team interaction. With regard to the main features of 
Tohochynskyi, O.; Yermak, S.; Popryzhna, A.; Tvrdon, M. \& Oleksiuk, N. (2021). Professionally oriented training of specialists to work in the conditions of the inclusive educational environment. Cypriot Journal of Educational Science. 16(3), $1244-1254$. https://doi.org/10.18844/cjes.v16i3.5844

the team of diversified specialists capable of working in the conditions of IE, we relate initiative, activeness, personal responsibility and concern of each educational entity, as well as cohesion and compatibility of all its members. The primary goal of work of such a team is successful adaptation and socialisation of children with SEN in the society. To achieve this goal, every psycho-pedagogical specialist should aim his/her activity towards the development of professional competences, establishment of ideas of personality-oriented education, of differentiated teaching and modern innovative pedagogical and psychological and social technologies on the basis of team interaction.

For the purpose of checking the effectiveness of the training system of specialists in the psychological pedagogical field to work in the conditions of IE, the final stage of the forming experiment was conducted, during which the author's methods were tested. In particular, in the process of theoretical bachelors' training in the specialties like 'Preschool education', 'Primary education', 'Practical psychology' and 'Social pedagogy', a combined approach (mono-subject and poly-subject) was implemented. As the pedagogical experiment revealed, such an approach was the most efficient and provided a purposeful, systematic and consistent process of training of the future psycho-pedagogical specialists during the 4 years of studies.

Besides that, the methodology for organisation of the team professional activity of the diversified specialists in the conditions of IEE was developed, which was tested in both the course of the theoretical training of the students and during their pedagogical practices. To provide bachelors with the corresponding teaching materials, we have developed and implemented the educational and methodological manuals and guidelines in the educational process of the teacher training institutions of higher education ('Pedagogical technologies of inclusive education', 'Organisation of the team professional activity of the psychopedagogical specialists in the conditions of inclusive educational environment') and methodological recommendations ('Professional activity of the psycho-pedagogical specialists in inclusive educational environment').

The empirical data received at the final stage of the forming experiment allowed us to identify the levels of professional competence of bachelors of the studied specialties. In order to confirm general positions of our study, we used the nonparametric criterion of Pearson. Processed in this way, generalised experimental data demonstrated significant differences between the indexes of the control and experimental groups. According to the method of mathematical statistics used by us, the empirical value exceeded its critical exponent $(=9.433>5.991=[<0.05])$. It gives a reason to state that the effect of changes is caused by the implementation of the author's system of specialists training of psycho-pedagogical field to work in the conditions of IEE.

The conducted study does not exhaust all the problems raised in the dissertation work. We consider the following issues as perspective directions of this problem: studying of theoretical and methodological approaches of foreign and domestic experience in training of psycho-pedagogical staff for complete general secondary and technical and vocational education and substantiation of the possibilities of introduction of the elements of the developed training system of psycho-pedagogical staff to the process of organisation of the postgraduate pedagogical education.

\section{References}

Appiah-Kubi, P. \& Annan, E. A (2020). Review of a collaborative online international learning. International Journal of Engineering Pedagogy, 10(1), 109-124. doi:10.3991/ijep.v10i1.11678

Atoum, E. A (2019). Spiral Software engineering model to inspire innovation and creativity of university students. International Journal of Engineering Pedagogy, 9(5), 7-23. doi:10.3991/ijep.v9i5.10993 
Tohochynskyi, O.; Yermak, S.; Popryzhna, A.; Tvrdon, M. \& Oleksiuk, N. (2021). Professionally oriented training of specialists to work in the conditions of the inclusive educational environment. Cypriot Journal of Educational Science. 16(3), $1244-1254$. https://doi.org/10.18844/cjes.v16i3.5844

Barton, L. (2018). Labels, markets and inclusive education. In Special education in Britain after Warnock (pp. 30-42). Abingdon-on-Thames, UK: Routledge. doi:10.4324/9780429490095-3

Billingsley, B., McLeskey, J. \& Crockett, C. (2019). Conceptualizing principal leadership for effective inclusive schools. In Handbook of leadership and administration for special education (pp. 306-332). Retrieved from https://books.google.com.ua/books?hl=uk\&lr=\&id=sdZiDwAAQBAJ\&oi=fnd\&pg=PT392\&dq=inclusive+education+ "effective+instructional+strategies"\&ots=uUh_Owhjnx\&sig=f4QrBRr9bkaut3ZVXTOj4Y_uGv8\&redir_esc=y\#v=one page\&q=inclusive\%20education\%20"effective\%20instructional\%20strategies"\&f=false

Clark, C., Dyson, A. \& Millward, A. (2018). Towards inclusive schools: mapping the field. In Towards inclusive schools? (pp. 164-178). Abingdon-on-Thames, UK: Routledge. doi:10.4324/9780429469084-12

Engelbrecht, P., Savolainen, H., Nel, M., Koskela, T. \& Okkolin, M. A. (2017). Making meaning of inclusive education: Classroom practices in Finnish and South African classrooms. Compare, Journal of Comparative and International Education, 47(5), 684-702. doi:10.1080/03057925.2016.1266927

Fabiano, G. A., Reddy, L. A. \& Dudek, C. M. (2017). Teacher coaching supported by formative assessment for improving classroom practices. School Psychology Quarterly, 33(2), 293-304. doi:10.1037/spq0000223

Haug, P. (2016). Understanding inclusive education: ideals and reality. Scandinavian Journal of Disability Research, 19(3), 206-217. doi:10.1080/15017419.2016.1224778

McLeskey, J., Barringer, M. -D., Billingsley, B., Brownell, M., Jackson, D., Kennedy, M., ... Ziegler, D. (2017). Highleverage practices in special education (pp. 4-136). Arlington, VA: Council for Exceptional Children, \& Collaboration for Effective Educator Development, Accountability and Reform. Retrieved from http://nemtss.unl.edu/files/2018/08/CEC-HLP-Web.pdf

Messiou, K. (2017). Research in the field of inclusive education: time for a rethink? International Journal of Inclusive Education, 21(2), 146-159. doi:10.1080/13603116.2016.1223184

Morina, A. (2017) Inclusive education in higher education: challenges and opportunities. European Journal of Special Needs Education, 32(1), 3-17. doi:10.1080/08856257.2016.1254964

O'Hanlon, C. Inclusive education in Europe. Abingdon-on-Thames, UK: Routledge. doi: 10.4324/9780203730409, eBook ISBN 9780203730409

Qvortrup, A. \& Qvortrup, L. (2018). Inclusion: dimensions of inclusion in education. International Journal of Inclusive Education, 22(7), 803-817. doi:10.1080/13603116.2017.1412506

Saloviita, T. (2018). How common are inclusive educational practices among Finnish teachers? International Journal of Inclusive Education, 22(5), 560-575. doi:10.1080/13603116.2017.1390001

Slee, R. (2018). Inclusive education: from policy to school implementation. In Towards inclusive schools? (pp. 30-41). Abingdon-on-Thames, UK: Routledge. Retrieved from www.taylorfrancis.com/books/e/9780429469084/chapters/10.4324/9780429469084-3

Tomlinson, S. (2018). A sociology of special and inclusive education: exploring the manufacture of inability. Abingdonon-Thames, UK: Taylor \& $\quad$ Francis. Retrieved from books.google.com.ua/books?hl=uk\&|r=\&id=9jkIDwAAQBAJ\&oi=fnd\&pg=PP1\&dq=inclusive+education\&ots=NdRe GKFc7B\&sig=pmbSN7dVokHb1Enb55mvEPPWdCk\&redir_esc=y\#v=onepage\&q=inclusive\%20education\& $f=$ false

Udvari-Solner, A. \& Thousand, J. (2018). Effective organisational instructional and curricular practices in inclusive schools and classrooms. In Towards inclusive schools? (pp. 147-163). Abingdon-on-Thames, UK: Routledge. doi:10.4324/9780429469084-11

Ware, L. (2018). The aftermath of the articulate debate: the invention of inclusive education. In Towards inclusive schools? (pp. 127-146). Abingdon-on-Thames, UK: Routledge. doi:10.4324/9780429469084-10 
Tohochynskyi, O.; Yermak, S.; Popryzhna, A.; Tvrdon, M. \& Oleksiuk, N. (2021). Professionally oriented training of specialists to work in the conditions of the inclusive educational environment. Cypriot Journal of Educational Science. 16(3), $1244-1254$. https://doi.org/10.18844/cjes.v16i3.5844

Yada, A. \& Savolainen, H. (2017). Japanese in-service teachers' attitudes toward inclusive education and self-efficacy for inclusive practices. Teaching and Teacher Education, 64, 222-229. doi: 10.1016/j.tate.2017.02.005 